\title{
PRETORIA RADIOCARBON DATES I
}

\author{
J. C. VOGEL and M. MARAIS
}

National Physical Research Laboratory, Pretoria, South Africa*

\section{INTRODUCTION}

In 1969 radiocarbon dating facilities were established at the National Physical Research Laboratory of the C.S.I.R. in Pretoria $\left(25^{\circ} 43^{\prime} \mathrm{S}\right.$ Lat, $28^{\circ} 21^{\prime}$ E Long; alt $1500 \mathrm{~m}$ ). The counters are situated in an underground room built of selected concrete and covered by ca. $12 \mathrm{~m}$ earth. In this room, the nucleonic component of cosmic radiation is practically absent and the meson flux is reduced by a factor of 3.5 as compared to the surface at sea level in Groningen, Netherlands. A neutron monitor which registers $30 \mathrm{cpm}$ on the surface, counts ca. $0.1 \mathrm{cpm}$ in the underground room.

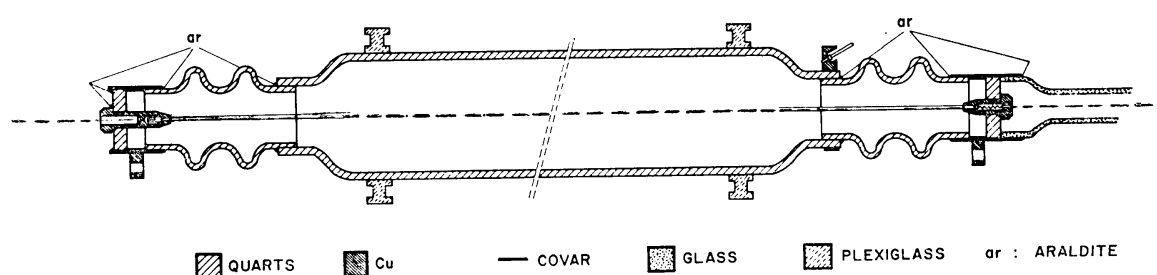

Fig. 1. Radiocarbon counter of quartz glass. Effective length $350 \mathrm{~mm}$, inner diam. $45 \mathrm{~mm}$, wire diam. $0.05 \mathrm{~mm}$.

The two small counters currently in use are of gold-plated quartz glass (Fig. 1). Their construction is designed to incorporate as little foreign material as possible and thus, keep the background, due to radioactive impurities, low. Around the counters are $3 \mathrm{~cm}$ old lead, an anticoincidence ring, and $10 \mathrm{~cm}$ selected lead. They have an effective volume of $0.56 \mathrm{~L}$ and an initial background of 0.5 and $0.65 \mathrm{cpm}$. No variation in background due to barometric pressure can be detected. At a filling pressure of $3.5 \mathrm{~atm}$ the modern count rate is $12.7 \mathrm{cpm}$; the figure of merit of the best counter is thus $\mathrm{A} / \sqrt{\mathrm{B}}=18$. These small counters are extremely useful for routine measurements since only a little more than $1 g$ of pure carbon is needed for an analysis. In two one-day counts a modern sample is measured to an accuracy of $0.54 \%$ or \pm 43 years.

The counting gas is $\mathrm{CO}_{2}$ prepared as described by Vogel and Waterbolk (1967), $\mathrm{C}^{13}$ analyses are performed on all samples and given with respect to the $\mathrm{PDB}$ standard. Corrections for variations in isotopic fractionation are applied to dates on organic material (wood, peat, charcoal, etc.), but not to marine carbonate (sea shells), because the isotopic fractionation is compensated for by the apparent age of surface ocean water. Dates on fresh water carbonate are also not corrected for isotopic fractionation since the initial $\mathrm{C}^{14}$ content is variable. In general, 1300

* Natural Isotopes Division, N.P.R.L., P.O. Box 395, Pretoria. 
\pm 500 years are to be subtracted from such dates (Münnich and Vogel, 1959).

Dates are reported in conventional radiocarbon years, i.e., using a half-life of 5568 years for $\mathrm{C}^{14}$. The descriptions are mainly compiled on the basis of information supplied by the submitters.

Thanks are due S. Talma of our laboratory for performing the $\mathrm{C}^{13}$ analyses, and to J. Schutte for dating assistance in the initial stages.

\section{SAMPLE DESCRIPTIONS}

\section{GEOLOGIC SAMPLES}

\section{Wolkberg Cave series, Transvaal}

Calcite samples from Wolkberg Cave $\left(24^{\circ} 05^{\prime} \mathrm{S}\right.$ Lat, $29^{\circ} 55^{\prime} \mathrm{E}$ Long) $32 \mathrm{~km}$ by rd. S of Pietersburg-Tzaneen Rd; on Wolkberg, dist. Pietersburg, Transvaal. Coll. and subm. 1969 by T. C. Partridge, 12 Cluny Rd., Forest Town, Johannesburg.

\section{Pta-285. Wolkberg T2}

$$
\begin{gathered}
10,370 \pm 100 \\
\mathbf{8 4 2 0} \text { B.c. } \\
\delta C^{13}=-4.49 \% \%
\end{gathered}
$$

Cienter of $45 \mathrm{~cm}$ diam. stalactite in Chamber 1, $50 \mathrm{~m}$ from entrance.

\section{Pta-105. Wolkberg T10(a)}

$$
\begin{gathered}
2820 \pm 60 \\
870 \text { B.c. } \\
\delta C^{13}=-1.14 \% \circ
\end{gathered}
$$

Outer part of younger-generation stalagmite $68 \mathrm{~m}$ above water table in Chamber 2, $170 \mathrm{~m}$ from entrance.

\section{Pta-106. Wolkberg T11(a)}

$$
\begin{gathered}
4690 \pm 65 \\
2740 \text { B.c. } \\
\delta C^{13}=-0.51 \% \circ
\end{gathered}
$$

Younger-calcite coating over older redissolved stalactite, $68 \mathrm{~m}$ above water table in Chamber 2, $170 \mathrm{~m}$ from entrance.

\section{Pta-174. Wolkberg T11(b)}

$$
\begin{aligned}
& 30,860 \pm 600 \\
& 28,910 \text { B.C. }
\end{aligned}
$$

Surface of same older redissolved stalactite as above.

Pta-169. Wolkberg T9

Older redissolved stalactite from $68 \mathrm{~m}$ above water table in Chamber 2, $170 \mathrm{~m}$ from entrance.

\section{Pta-104. Wolkberg T 20}

$$
\begin{aligned}
& 21,100 \pm 200 \\
& 19,150 \text { B.c. } \\
& \delta C^{13}=+1.87 \% \circ
\end{aligned}
$$

Younger-generation stalactite $38 \mathrm{~m}$ above water table, from wall of lower passage, ca. $360 \mathrm{~m}$ from entrance.

General Comment: outer layers of all samples etched off with dilute acid and inner carbonate dated. No correction for isotopic fractionation. 
Dates of freshwater calcite may be up to $1300 \mathrm{yr}$ too old (Münnich and Vogel, 1959). Varying ages show no indication of discrete periods of precipitation. T11 suggests period of dissolution between 30,860 B.P. and 4690 в.P.

Pta-103. Ficus Cave, Transvaal A.D. 1620 $330 \pm 50$ $\delta C^{13}=-3.77 \%$

Fragments, younger-generation stalactite, $23 \mathrm{~m}$ above water table, from Ficus Cave, Makapan Valley (24 $10^{\prime} \mathrm{S}$ Lat, 29 $15^{\prime} \mathrm{E}$ Long), $23 \mathrm{~km}$ E of Potgietersrust, Transvaal. Coll. and subm. 1969 by T. C. Partridge. Comment: outer layers etched off with acid, inner part measured. Calcite precipitation apparently continued to recent times.

\section{Sterkfontein series, Transvaal}

Calcite samples from Sterkfontein Cave $\left(26^{\circ} 02^{\prime} \mathrm{S}\right.$ Lat, $27^{\circ} 42^{\prime} \mathrm{E}$ Long), $6 \mathrm{~km} \mathrm{NW}$ of Krugersdorp, Transvaal. Coll. and subm. 1969 by T. C. Partridge.

Pta-102. Sterkfontein 2

Sample of younger-generation stalactite, ca. $4.5 \mathrm{~m}$ above water table.

Pta-108. Sterkfontein 11(a) table.

Center part of younger-generation stalagmite, ca. $4.5 \mathrm{~m}$ above water

Pta-109. Sterkfontein 11(b)

$>\mathbf{5 0 , 0 0 0}$

Outer part of same younger-generation stalagmite as above.

General Comment: outer layer of all samples etched off with acid, inner carbonate measured. Even younger-generation stalactite from this cave underlying Sterkfontein Australopithecus cave (and thus of later date) is $>50,000$ yr.

\section{Morelettaspruit series, Transvaal}

Where Morelettaspruit crosses Silverton Ridge, Meyerspark, Pretoria (25 $45^{\circ} \mathrm{S}$ Lat, $28^{\circ} 16^{\prime} \mathrm{E}$ Long), Transvaal, $1.4 \mathrm{~m}$ peat overlies $0.8 \mathrm{~m}$ sand and clay, $0.6 \mathrm{~m}$ coarse gravel, peat, and clay. Samples coll. and subm. 1969 by P. Verhoef and J. C. Vogel.

\section{Pta-129. Morelettaspruit 1.4 m}

$$
\begin{aligned}
& \mathbf{4 4 0} \pm \mathbf{4 0} \\
& \text { A.D. } 1510 \\
& \delta C^{13}=-23.3 \%
\end{aligned}
$$

Sample from bottom of upper peat layer at $1.4 \mathrm{~m}$ depth.

\section{Pta-128. Morelettaspruit $2.8 \mathrm{~m}$}

$5220 \pm 55$

Sample from top of lower peat layer at $2.8 \mathrm{~m}$ depth.

General Comment: pretreated with acid only. Gravel deposit, common in 
stream beds in region, deposited between 5220 and 440 yr ago, i.e., apparently before occupation by agriculturalists.

\section{Tietieshaai series, Cape Province}

On coast at Tietiesbaai ( $31^{\circ} 10^{\prime} \mathrm{S}$ Lat, $17^{\circ} .45^{\prime} \mathrm{E}$ Long), $47 \mathrm{~km} \mathrm{~W}$ of Bitterfontein, Namaqualand, Cape Prov., series of 6 emerged beaches occurs. Lowest 3 at 2, 5, and $7 \mathrm{~m}$ are covered by stabilized berm but exposed by prospecting trenches. Shells coll. and subm. 1969 by A. J. Carrington, South African Mus., Cape Town.

\section{Pta-090. Tietiesbaai, 2m}

$$
\begin{array}{r}
\mathbf{3 4 0} \pm \mathbf{5 0} \\
\text { A.d. } 1610 \\
\delta C^{13}=+1.1 \%
\end{array}
$$

Anthropod shell from top of $2 \mathrm{~m}$ emerged beach (back-beach environment) below ca. $2 \mathrm{~m}$ berm on coastal farm Tietiesbaai. Comment: unexpectedly young age suggests sample does not actually date $2 \mathrm{~m}$ beach.

\section{Pta-091. Karoetjieskop A, 5 m}

$$
\begin{aligned}
& >\mathbf{4 7 , 5 0 0} \\
\delta C^{13}= & +1.8 \% 0
\end{aligned}
$$

Anthropod and mollusk shells from $5 \mathrm{~m}$ emerged beach (back-beach environment) below ca. $3 \mathrm{~m}$ berm on coastal farm Karoetjieskop.

\section{Ptan092. Karoetjieskop B, 5 m}

$$
\delta C^{13}=+0.2 \%
$$

Anthropod and mollusk shells from $5 \mathrm{~m}$ emerged beach (back-beach environment) below ca. $4 \mathrm{~m}$ berm on farm Karoetjieskop.

\section{Pta-093. Karoetjieskop C, $7 \mathrm{~m}$}

$$
\begin{aligned}
& >\mathbf{5 0 , 0 0 0} \\
\delta C^{13} & =-0.2 \%
\end{aligned}
$$

Mollusk shells from $7 \mathrm{~m}$ emerged beach (back-beach environment) below ca. $5 \mathrm{~m}$ sand and shell midden on farm Karoetjieskop.

General Comment: about half of carbonate removed with dilute acid; the rest dated. No $\mathrm{C}^{13}$ corrections made. Results show $+5 \mathrm{~m}$ and $+7 \mathrm{~m}$ beaches not of Pleniglacial age but either Early Glacial or Preglacial. Cf. dates for $+2 \mathrm{~m}$ terrace at Oranjemund of ca. 35,000 and 38,100 B.P. (R., 1970 , v. 12, p. 450) and Saldanha Bay series, below.

\section{Pta-161. Anyskop, Cape Province}

$35,930 \pm 1000$ 33,980 в.C.

$$
\delta C^{13}=-25.2 \%
$$

Carboniferous clay from Anyskop (32 $57^{\prime} 30^{\prime \prime} \mathrm{S}$ Lat, $18^{\circ} 05^{\prime} \mathrm{E}$ Long), Vredenburg dist., Cape Prov., $4.6 \mathrm{~m}$ below surface and $+24 \mathrm{~m}$, underlying phosphate layer, sand, and tufa in prospecting pit. Coll. 1969, subm. 1970 by H. N. Visser, Geol. Survey, Pretoria. Comment: pretreated with acid only. Date suggests phosphate layer is late Pleistocene.

\section{Saldanha Bay series, Cape Province}

Shell samples from emerged beaches at Peninsula, Saldanba Bay $\left(33^{\circ}\right.$ 
$05^{\prime} \mathrm{S}$ Lat, $18^{\circ} 00^{\prime} \mathrm{E}$ Long), Cape Prov. Coll. and subm. 1969 by R. J. Parker, Marine Geol. Sec., Inst. of Oceanography, Univ. Cape Town.

\section{Pta-094. Kreeftebaai A}

$40,200 \pm 1300$ 38,250 в.C.

$\delta C^{13}=+0.33 \%$

Shell fragments assoc. with 3 to $5 \mathrm{~m}$ emerged beach, from outcrop on emerged wave-cut terrace at Kreeftebaai.

\section{Pta-095. Luisterhoek B}

\section{6,250 в.C.}

Shell fragments assoc. with 3 to $5 \mathrm{~m}$ emerged beach, from outcrop on emerged wave-cut terrace at Luisterhoek.$$
48,500+3600
$$ \\ Pta-096. Churchhaven C \\ 46,550 в.C. \\ $-2900$ \\ $\delta C^{13}=+1.31 \%$}

Loose shells assoc. with a 3 to $5 \mathrm{~m}$ emerged beach, exposed in unconsolidated dune cliff face at Churchhaven, $+4.2 \mathrm{~m}, 3 \mathrm{~m}$ below top of cliff.

\section{Pta-097. Elandspunt D}

$41,100 \pm 1200$ 39,150 B.C.

$\delta C^{13}=+0.83 \%$

Shell fragments assoc. with $15 \mathrm{~m}$ emerged beach, exposed in cliff face at Elandspunt, ca. $+6.5 \mathrm{~m}$ and 6 to $9 \mathrm{~m}$ below top of cliff.

Pta-098. Elandspunt E

Shell fragments from same layer as Elandspunt D.

$$
\delta C^{13}=+2.14 \%
$$

General Comment: before being submitted, Samples A, B, D, E were crushed, washed in boiling water, and secondary carbonate was removed with knife. In lab. half of carbonate etched off with acid; inner part measured. As usual, no correction for $\mathrm{C}^{13}$. Dates may be too young since boiling shells in water can introduce contamination. Small amounts of secondary carbonate can also make dates too young: 3 to $5 \mathrm{~m}$ beach thus at least 48,000 в.P., and pre-Pleniglacial, while $15 \mathrm{~m}$ beach is $>49,500$ в.P. (Pta-098). Compare Tietiesbaai series, above.

Pta-171. Cape Flats, Cape Province $>40,500$

Piece of wood found at $-4 \mathrm{~m}$ in Borehole 223, cor. of Klipfontein Rd. and 5th Ave. (33 57' 48" S Lat, $18^{\circ} 30^{\prime} 31^{\prime \prime}$ E Long), Athlone, Cape Town. Coll. by W. R. Ross; subm. 1969 by M. R. Henzen, N.I.W.R., C.S.I.R., Pretoria. Comment: pretreated with acid only. Sand filling of Cape Flats Basin thus not of Postglacial date. Compare W-246: >38,000 
B.P. (Science, 1956, v. 123, p. 443), Y-49: >38,000 B.P. and Y-106: >36,300 (Science, 1957, v. 126, p. 918) for similar samples.

Pta-250. Bredasdorp, Cape Province $\begin{aligned} & >\mathbf{4 6 , 0 0 0} \\ \delta C^{13} & =-25.3 \%\end{aligned}$

Brown coal 0.6 to $1.8 \mathrm{~m}$ deep in lenses in marsh deposit on Malmesbury rocks, exposed during excavation for dam on Tierfontein Farm, Bredasclorp (34 $32^{\prime} \mathrm{S}$ Lat, $20^{\circ} 25^{\prime} \mathrm{E}$ Long), Cape Prov. Coll. and subm. 1970 by H. N. Visser. Comment: pretreated with acid only. Deposit not of recent date.

\section{Cape St. Francis series, Cape Province}

Shell samples dredged from submerged beaches at different depths off Cape St. Francis, Cape Prov. Coll. and subm. 1969 by R. A. Slater, Marine Geol. Sec., Inst. of Oceanog., Univ. Cape Town.

Pta-183. Cape St. Francis DR-169

$7580 \pm 70$

5630 в.c.

$\delta C^{13}=+2.4 \%$

Oyster shell, $-51 \mathrm{~m}\left(34^{\circ} 05.0^{\prime} \mathrm{S}\right.$ Lat, $24^{\circ} 11.8^{\prime} \mathrm{E}$ Long).

\section{Pta-265. Cape St. Francis DR-175}

$14,510 \pm 120$

12,560 в.с.

$\delta C^{13}=+2.5 \%$

Oyster shell, $-112 \mathrm{~m}$ (34 $31.0^{\prime} \mathrm{S}$ Lat, $24^{\circ} 30.0^{\prime} \mathrm{E}$ Long).

\section{Pta-254. Cape St. Francis DR-192 \\ 11,720 в.c.$$
\delta C^{13}=+1.5 \%
$$

$13,670 \pm 120$

Calcareous algae, $-115 \mathrm{~m}\left(34^{\circ} 24.2^{\prime} \mathrm{S}\right.$ Lat, $25^{\circ} 00.0^{\prime} \mathrm{E}$ Long).

Pta-185. Cape St. Francis DR-183(c)

$12,990 \pm 110$

11,040 в.c.

$$
\delta C^{13}=+1.6 \%
$$

Calcareous algae, $-120 \mathrm{~m}$ ( $34^{\circ} 28.9^{\prime} \mathrm{S}$ Lat, $24^{\circ} 42.3^{\prime} \mathrm{E}$ Long).

\section{Pta-182. Cape St. Francis DR-175(c)}

$16,990 \pm 160$

15,040 в.C.

Pecten shell, $-130 \mathrm{~m}$ (34 $31.0^{\prime} \mathrm{S}$ Lat, $24^{\circ} 30.0^{\prime} \mathrm{E}$ Long).

$\delta C^{13}=+1.8 \%$ o

General Comment: outer half of all samples etched away with acid, inner carbonate measured. Samples date rise in sea level during Late GlacialHolocene and indicate lowest sea level $(-130 \mathrm{~m})$ during Last Glacial occurred ca. 17,000 B.P.

II. ARCHAEOLOGIC SAMPLES

A. Stone Age of Southern Africa

Pta-256. Tuinplaas, Transvaal

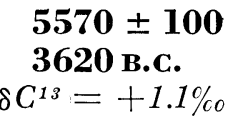


Calcareous crust on bone from fossil site of Tuinplaas $\left(25^{\circ} 55^{\prime} \mathrm{S}\right.$ Lat, $28^{\circ} 45^{\prime}$ E Long), $13 \mathrm{~km}$ E of Settlers, Springbokvlakte, Transvaal. Bones assoc. with Tuinplaas skeleton buried in $45 \mathrm{~cm}$ calcrete at ca. $90 \mathrm{~cm}$ depth. Subm. 1969 by A. Hughes, Univ. of Witwatersrand, Johannesburg. Comment: since bone contains no collagen, secondary calcite dated, minimum for Middle Stone age skeleton.

\section{Heuningneskrans series, Transvaal}

Rock shelter on farm Heuningneskrans No. 476 (24ㅇ $36^{\prime}$ S Lat, $30^{\circ}$ $39^{\prime}$ E Long), $18 \mathrm{~km} \mathrm{~N}$ of Ohrigstad, Lydenburg dist., Transvaal, excavated by P. Beaumont in 1968. Sediment contains 3 Later Stone age (Smithfield) strata: Stratum 3 from 0 to $76 \mathrm{~cm}$, Stratum 2 from 76 to $152 \mathrm{~cm}$ and Stratum 1 from $152 \mathrm{~cm}$, to bedrock at $610 \mathrm{~cm}$. Samples coll. and subm. by P. Beaumont, Bernard Price Inst. for Palaeontol., Univ. of Witwatersrand, Johannesburg.

\section{Pta-112. Heuningneskrans 27"}

$$
\delta C^{13}=-18.6 \%
$$

Charred bone from lower part of Stratum 3 at 45 to $70 \mathrm{~cm}$ depth in Sq. AB assoc. with early Later Stone age industry with high percentage of scrapers. Comment: pretreated as for charred bone (Vogel and Waterbolk, 1963) and alkali soluble fraction measured.

\section{Pta-099. Heuningneskrans 45"}

$$
\delta C^{13}=-24.3 \%
$$

Charcoal fragments from top of Stratum 2 at 76 to $107 \mathrm{~cm}$ depth in Sq. A10 assoc. with early Later Stone age industry. Comment: pretreated with acid and alkali.

\section{Pta-114. Heuningneskrans 66"}

$$
\begin{gathered}
10,430 \pm 150 \\
8480 \text { B.C. }
\end{gathered}
$$

Charred bone from top of Stratum 1 at 145 to $168 \mathrm{~cm}$ depth in Sq. A9 assoc. with early Later Stone age industry. Comment: pretreated as Pta-112 above.

\section{Pta-100. Heuningneskrans 93"}

$13,100 \pm 110$

$$
\begin{gathered}
\text { 11,150 B.C. } \\
\delta C^{13}=-25.2 \%
\end{gathered}
$$

Charcoal fragments from Stratum 1 at 220 to $235 \mathrm{~cm}$ depth in Sqs. A12 and A13. Comment: pretreated with acid and alkali.

\section{Pta-233. Heuningneskrans 172"}

$$
\begin{gathered}
11,220 \pm 140 \\
9270 \text { B.C. } \\
\delta C^{13}=-9.5 \% 0
\end{gathered}
$$

Calcrete cementing soil at 430 to $436 \mathrm{~cm}$ depth in Sq. C11. Comment: half of carbonate etched away with dilute acid and the rest dated. This is no date for level but average for secondary cementing episode; since 
apparent age of freshwater carbonate is usually $1300 \mathrm{yr}$ (Münnich and Vogel, 1959), cementing probably took place ca. 10,000 B.P.

\section{Pta-101. Heuningneskrans 174" \\ 22,680 B.C. \\ $\delta C^{13}=-14.5 \%$}

$24,630 \pm 300$

Charred bone from hearth at 435 to $442 \mathrm{~cm}$ depth in Sq. A12 assoc. with early Later Stone age indlustry. Comment: pretreated as Pta-112 above.

General Comment: dates indicate Stratum 1 top and Stratum 2 contemporaneous with Later Stone age at nearby Bushman Rock Shelter (R., 1970 , v. 12, p. 458). Pta-101 shows high antiquity of Later Stone age culture, confirming Rose Cottage series, below.

\section{Pta-004. Mlaula Shelter 2, Swaziland}

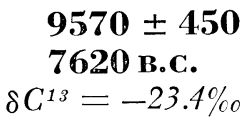

Burnt bone fragments, 80 to $100 \mathrm{~cm}$ deep, from Later Stone age rock shelter of Mlaula, ca. $8 \mathrm{~km} \mathrm{SW}$ of Mlaula $\left(26^{\circ} 12^{\prime} \mathrm{S} \mathrm{Lat}, 32^{\circ} 01^{\prime} \mathrm{E}\right.$ Long), Swaziland. Coll. 1965, subm. 1967 by P. Beaumont. Comment: pretreated as for burnt bone. Cf. Y-1996: $9370 \pm 160$ for same deposit (R., 1969, v. 11, p. 646).

\section{Pta-163. Umhlanga Rocks, Natal}

$$
\begin{aligned}
& \mathbf{2 5 0} \pm \mathbf{3 5} \\
& \text { A.D. } 1700 \\
& \delta C^{13}=-26.6 \% \text { o }
\end{aligned}
$$

Charcoal $13 \mathrm{~cm}$ below surface, from hearth in open midden site, $150 \mathrm{~m} \mathrm{~N}$ of lighthouse, Umhlanga Rocks beach $\left(29^{\circ} 41.5^{\prime} \mathrm{S}\right.$ Lat, $31^{\circ} 07^{\prime}$ E Long), $18 \mathrm{~km} \mathrm{NE}$ of Durban, Natal, assoc. with Later Stone age Wilton industry. Coll. by R. C. Walsh; subm. 1969 by O. Davies, Natal Mus., Pietermaritzburg. Comment: pretreated with acid and alkali. Date shows Later Stone age people lived on coast after arrival of Bantu in area.

\section{Pta-087. Munro's site skeleton, Orange Free State A.D. 1100 \\ $850 \pm 60$ \\ $\delta C^{13}=-11.2 \%$}

Bone from leg of skeleton B 10-20 excavated at Munro's site on Vaal R., $1.6 \mathrm{~km}$ upstream from Oppermansdrift dam $\left(24^{\circ} 42^{\prime} \mathrm{S}\right.$ Lat, $25^{\circ} 33^{\prime} \mathrm{E}$ Long), Orange Free State (Mason, 1969). Assoc. with Smithfield Industry. Coll. 1968, subm. 1969 by R. J. Mason, Univ. of Witwatersrand, Johannesburg. Comment: inorganic salts removed by repeated treatment with dilute acid and collagen dated. First Later Stone age skeleton dated in area. Cf. Riet R. skeletons, below.

\section{Rose Cottage series, Orange Free State}

Further samples from Rose Cottage cave near Ladybrand $\left(29^{\circ} 15^{\prime} \mathrm{S}\right.$ Lat, $27^{\circ} 30^{\prime}$ E Long), Orange Free State, analyzed (see R., 1970, v. 12, p. 462). Coll. 1962 by P. Beaumont; subm. 1968 by R. J. Mason. 


\section{Pta-350. Rose Cottage sherd}

$$
\begin{aligned}
& \quad \mathbf{6 1 0} \pm \mathbf{5 0} \\
& \text { A.D. 1340 } \\
& \delta C^{13}=-20.8 \%
\end{aligned}
$$

Sherd of grass-tempered pot from 30 to $37 \mathrm{~cm}$ depth in Sq. Fh in uppermost Wilton layer. Comment: $80 \mathrm{~g}$ sherd contained enough charred grass for analysis. Pretreated with acid. Such potsherds should prove useful to date early pottery traditions in S Africa.

\section{Pta-211. Rose Cottage 4' $5^{\prime \prime}$}

$29,430 \pm 520$

27,480 в.c.

$\delta C^{13}=-23.5 \%$

Finely dispersed charcoal and ash from Sq. Jf at $135 \mathrm{~cm}$ depth in base of pre-Wilton layer. Comment: pretreated with acid and alkali. Since all carbon dissolved in hot alkali, this fraction was analyzed. Date could be too young, but, since older than GrN-5300: 25,640 \pm 220 B.P. for comparable level at $146 \mathrm{~cm}$ (erroneously quoted as $176 \mathrm{~cm}$ in R., 1970, v. 12, p. 462) it is considered reliable. Confirms high age of lst Later Stone age in cave. Both samples overlie primitive Later Stone age assemblage in Malan's (1952) "sterile" layer.

\section{Pta-213. Rose Cottage 10'10"}

$$
\begin{aligned}
&>\mathbf{5 0 , 2 0 0} \\
& \delta C^{13}=-23.8 \% o
\end{aligned}
$$

Fine charcoal and sand from Sq. Hd at $330 \mathrm{~cm}$ depth in top of Upper Magosian layer. Comment: pretreated with acid and alkali. Since all carbon dissolved in alkali, this fraction was measured. Date could be too young. Confirms high age of Magosian at site.

Pta-214. Rose Cottage 12'4" soluble frac.

\section{Pta-231. Rose Cottage 12'4" insoluble frac.}

Charcoal from Sq. Ie at $380 \mathrm{~cm}$ depth in lower hearth of Upper Magosian. Comment: pretreated with acid and alkali; both alkali soluble and insoluble fractions measured with similar results.

\section{Pta-001. Rose Cottage 12'}

$36,100 \pm 2000$

Small sample of fine charcoal from outside grid in Upper Magosian layer. Comment: pretreated with acid and alkali. On basis of other minimum dates for Magosian, above, this sample too young and must have been contaminated.

General Comment: these dates and those for Heuningneskrans, above, prove that Later Stone age in South Africa goes back beyond 24,000 B.P., double age hitherto assumed, and that "Magosian" of Rose Cottage is older than 50,000 B.P., as at Montagu Cave (R., 1970, v. 12, p. 460).

\section{Riet River series, Orange Free State}

Two graves at Site OFD 1 on bank of Riet R., farm Koppieskraal (29 $19^{\circ} \mathrm{S}$ Lat, $24^{\circ} 57^{\prime} \mathrm{E}$ Long), $12 \mathrm{~km} \mathrm{~N}$ of Koffiefontein, Orange Free 
State, excavated in 1969 (Humphreys and Maggs, 1970). Graves possibly related to nearby stone-built settlement. In past 60 or more graves found here (Van Riet Lowe, 1931). Coll. and subm. 1970 by T. Maggs, Dept. of Archaeol., Univ. Cape Town, and A.J.B. Humphreys, McGregor Mus., Kimberley.

\section{Pta-247. Riet River Skeleton 1}

$$
\begin{array}{r}
\mathbf{1 1 0} \pm \mathbf{5 0} \\
\text { A.D. } 1840 \\
\delta C^{13}=-9.2 \%
\end{array}
$$

Ribs of human skeleton $1.2 \mathrm{~m}$ below surface from Burial 1. Ostrich eggshell bead headband of Later Stone age type, and copper pendant found in assoc. Pendant preserved portion of hair and skin of scalp. Hair decorated with specularite. Red ocher used on burial.

\section{Pta-248. Riet River Skeleton 2}

Ribs of human skeleton from Burial 2, $1 \mathrm{~m}$ below surface.

General Comment: inorganic salts removed with cold acid. Collagen measured. From $\mathrm{C}^{14}$ calibration curve (Vogel, 1970) most probable historic dates are either A.D. 1845 or A.D. 1690 for Skeleton 1 and either A.D. 1590 or A.D. 1475 for Skeleton 2.

\section{Doornfontein series, Cape Province}

Ancient specularite working on farm Doornfontein M82, $10 \mathrm{~km}$ NNW of Postmasburg (28 $18^{\prime} \mathrm{S}$ Lat, $23^{\circ} 05^{\prime}$ E Long), Cape Prov., excavated by P. Beaumont and A. K. Boshier. Coll. and subm. 1969 by P. Beaumont.

\section{Pta-186. Doornfontein 27"-39"}

$$
\begin{gathered}
1120 \pm 40 \\
\text { A.D. 830 } \\
\delta C^{13}=-21.7 \% 0
\end{gathered}
$$

Scattered charcoal nodules in middle levels of mining rubble in Chamber 3, 70 to $100 \mathrm{~cm}$ below surface, assoc. with bush-boskop skeletal remains and crude Later Stone age artifacts and "Hottentot" pottery.

\section{Pta-187. Doornfontein 45"-52"}

$$
\begin{gathered}
1120 \pm 40 \\
\text { A.D. 830 } \\
\delta C^{13}=-24.5 \%
\end{gathered}
$$

Scattered charcoal nodules from basal levels of mining rubble in Chamber 3,115 to $130 \mathrm{~cm}$ below surface (bedrock), assoc. with skeletal remains and crude Later Stone age artifacts.

General Comment: pretreated with acid and alkali.

\section{Pta-251. Baviaanskloof, Cape Province}

$12,650 \pm 100$ 10,700 B.c. $\delta C^{13}=-23.9 \%$

Small charcoal sample from cave in Baviaanskloof Mts. $\left(33^{\circ} 30^{\prime} \mathrm{S}\right.$ Lat, $23^{\circ} 40^{\prime}$ E Long), ca. $12 \mathrm{~km}$ SE of Willowmore, Cape Prov. Middle Stone age industry reported in cave sediment. Coll. and subm. 1969 by 
K. Jolly, Cape Town. Comment: pretreated with acid only. Too young for Middle Stone age.

\section{Pta-261. Hofmeyer, Cape Province}

$$
\begin{aligned}
& 3020 \pm 90 \\
& 1070 \text { B.C. }
\end{aligned}
$$

Calcite crust on animal horn assoc. with fossil skull found no Hofmeyer (31 $39^{\prime} \mathrm{S}$ Lat, $25^{\circ} 49^{\prime} \mathrm{E}$ Long), Cape Prov. Subm. 1969 by H. de Villiers and A. Hughes, Univ. of Witwatersrand, Johannesburg. Comment: since bone contains no collagen, secondary calcite crust date, only minimum for much older skull.

\section{Pta-014. Robberg Cave D, Cape Province}

$$
1925 \pm 33
$$

A.D. 50

$\delta C^{13}=+3.4 \%$

Patella shell $90 \mathrm{~cm}$ below surface at back of Cave D, S side of Robberg Pen. (34 06.5' S Lat, $23^{\circ} 24.5^{\prime}$ E Long), near Cape Seal, Plettenberg Bay, Cape Prov. Four shells found with painted burial stone on human skeleton. Coll. 1917 by W. G. Sharples; subm. 1969 by J. Rudner, S. African Mus., Cape Town. Comment: pretreated with acid. Date of 2285 \pm 105 B.P. (GX-1397) for shells found with painted burial stone at Klasies R. Mouth (Singer, 1969).

\section{Lower Numas Cave series, SW Africa}

Cave with rock paintings in Lower Numas Ravine $\left(21^{\circ} 08^{\prime} \mathrm{S}\right.$ Lat, $14^{\circ} 26^{\prime} \mathrm{E}$ Long), Brandberg, Omaruru dist., SW Africa. Testhole revealed fine Wilton industry without pottery (Rudner, 1957). Samples coll. and subm. 1969 by J. Rudner.

\section{Pta-178. Lower Numas Cave 1}

$2890 \pm 65$

940 B.C.

Charcoal from hearth $7 \mathrm{~cm}$ below surface in testhole.

\section{Pta-179. Lower Numas Cave 2}

Charcoal from hearth $15 \mathrm{~cm}$ below surface in testhole.

$$
\delta C^{13}=-22.0 \%
$$

General Comment: both samples pretreated with acid and alkali. Another date from Brandberg for Wilton industry with copper beads and pottery in Numas Entrance shelter is SR-46: $870 \pm 100$ (MacCalman, 1965). See also Pta-177, below.

\section{Pta-177. Numas Plateau, SW Africa}

$$
265 \pm 50
$$

\section{A.D. 1685}

$\delta C^{13}=-23.7 \%$ o

Charcoal from fireplace covered with stone cairn, below so-called Okapo frieze, on Numas Plateau $\left(21^{\circ} 08^{\prime} \mathrm{S}\right.$ Lat, $14^{\circ} 30^{\prime} \mathrm{E}$ Long; alt 2250 m), Brandberg, Omaruru dist., SW Africa. Coll. and subm. 1969 by J. Rudner. Potsherds of Bergdama or Hottentot type found in ash. Com$m e n t$ : pretreated with acid and alkali. 
Pta-212. Benfica, Angola

$1810 \pm \mathbf{5 0}$
A.D. 140
$\delta C^{13}=-22.8 \%$

Charcoal, 35 to $40 \mathrm{~cm}$ deep, from Strandloper kitchen midden near coast at Benfica, $17 \mathrm{~km} \mathrm{~S}$ of Luanda ( $8^{\circ} 50^{\prime} \mathrm{S}$ Lat, $13^{\circ} 15^{\prime} \mathrm{E}$ Long), Angola. Layer also contained shells, bones, and pottery (Dos Santos and Ervedosa, 1970). Coll. and subm. 1970 by J. R. Dos Santos, Jr., Univ. of Luanda, Angola. Comment: pretreated with acid and alkali. This early date for pottery on Angolan coast concurs with early pottery tradition in Zambia.

Mungo series, Angola

Rock shelter of Caninguiri, adm. of Mungo ( $11^{\circ} 57^{\prime} \mathrm{S}$ Lat, $16^{\circ} 28^{\prime} \mathrm{E}$ Long), Nova Lisboa dist., Angola, contains ca. $2 \mathrm{~m}$ sediment with Wilton type industry and rock paintings. Samples coll. and subm. 1970 by J. R. Dos Santos, Jr.

\section{Pta-238. Mungo 3}

$7840 \pm 80$

Charcoal from 85 to $100 \mathrm{~cm}$ depth.

\section{Pta-239. Mungo 5} 5890 B.C.

Charcoal from 160 to $196 \mathrm{~cm}$ depth.

\section{Pta-240. Mungo 6} $\delta C^{13}=-25.4 \%$

Charcoal from 196 to $220 \mathrm{~cm}$ depth.

General Comment: all samples pretreated with acid and alkali. Dates comparable with other early Later Stone age dates in Angola, e.g., UCLA172: $12,970 \pm 250$ в.P. and UCLA-167: $6830 \pm 200$ в.P. (R., 1963, v. 5, p. 17).

\section{B. Iron Age of Southern Africa}

\section{Pta-136. Klipriviersberg 4, Transvaal}

$$
227 \pm 46
$$

A.D. 1723

$\delta C^{13}=-23.1 \%$

Further sample from lowest level of Iron age stone-wall settlement of Uitkomst culture at Klipriviersberg ca. $7 \mathrm{~km} \mathrm{~S}$ of Johannesburg $\left(26^{\circ}\right.$ $11^{\prime}$ S Lat, $28^{\circ} 02^{\prime}$ E Long), Transvaal (see R., 1967, v. 9, p. 148). Coll. and subm. 1969 by R. J. Mason, Univ. of Witwatersrand, Johannesburg. Comment: pretreated with acid only. Corrected most probable date derived from $\mathrm{C}^{14}$ calibration curve (Vogel, 1970) is A.D. 1645 in accordance with other dates for similar sites (R., 1970, v. 12, p. 465 ff.).

\section{Pta-002. Ndumu, Zululand}
$1320 \pm 40$
A.D. 630
$\delta C^{13}=-12.8 \%$

Charcoal found in and around iron furnace in Ndumu Game Reserve, junction of Usutu and Pongola Rivers (32 $20^{\prime} \mathrm{E}$ Long, $26^{\circ} 51^{\prime} \mathrm{S}$ 
Lat), Zululand (Dutton, 1970). Coll. 1968, subm. 1969 by P. Dutton and P. de Moor, Ndumu, Zululand. Comment: pretreated with acid and alkali. For similar early Iron age dates from Swaziland, see Castle Cavern series: GrN-5022: $1530 \pm$ 30; GrN-5315: $1550 \pm 30$ (R., 1970, v. 12, p. 464).

\section{Pta-162. Blackburn Ridge, Natal}

$900 \pm 40$

A.D. 1050

Charcoal from hearth 28 to $30 \mathrm{~cm}$ below surface, during systematic excavation of hut with $\mathrm{NC}_{2}$ pottery at Blackburn village site $\left(29^{\circ} 41^{\prime} \mathrm{S}\right.$ Lat, $31^{\circ} 06^{\prime}$ E Long), near Umhlanga Rocks, Natal. Coll. and subm. 1969 by O. Davies. Comment: pretreated with acid and alkali. Minimum date for arrival of Bantu S of Tugela R. Compare Ndumu, above.

\section{Pta-234. Kapako, SW Africa}

$$
\begin{aligned}
& \mathbf{1 1 0 0} \pm \mathbf{5 0} \\
& \text { A.D. 850 } \\
& \delta C^{13}=-25.4 \% \text { o }
\end{aligned}
$$

Charcoal at $70 \mathrm{~cm}$ depth from test pit at Iron age site of Kapako $\left(17^{\circ}\right.$ $55^{\prime} \mathrm{S}$ Lat, $19^{\circ} 40^{\prime} \mathrm{E}$ Long), W of Runtu on Okavango R., SW Africa. Assoc. finds were potsherds, bone, isolated stone artifacts. Coll. 1968, subm. 1970 by B. Sandelowsky-Pendleton, State Mus., Windhoek, SW Africa. Comment: pretreated with acid and alkali. Compare Benfica, above, which has similar pottery.

\section{Pta-236. Vungu Vungu, SW Africa}

$290 \pm 45$
A.D. 1660
$\delta C^{13}=-24.9 \%$

Charcoal at 25 to $23 \mathrm{~cm}$ depth from Iron age site at Vungu Vungu (17 $53^{\prime}$ S Lat, $19^{\circ} 51^{\prime}$ E Long), E of Runtu, on Okavango R., SW Africa. Potsherds, bone, glass beads, ostrich-eggshell beads, and shells found in assoc. Coll. 1969, subm. 1970 by B. Sandelowsky-Pendleton. Comment: pretreated with acid and alkali.

\section{Pta-235. Dikundu B 1973/E, SW Africa}

A.D. 1830

$120 \pm 50$

$\delta C^{13}=-26.0 \%$

Charcoal from bottom of iron-smelting furnace at $75 \mathrm{~cm}$ depth, Omuramba Dikundu (18 $08^{\circ} \mathrm{S}$ Lat, $21^{\circ} 40^{\prime}$ E Long), ca. $19 \mathrm{~km} \mathrm{SW}$ of Andara on Okavango R., SW Africa. Coll. 1969, subm. 1970 by B. Sandelowsky-Pendleton. Comment: pretreated with acid and alkali.

\section{Varia}

\section{Pta-170. Egyptian Mummy}

Piece from wrap of Egyptian mummy with naturalistic portrait of young man. Exact origin unknown. Now in Nat. Cult. Hist. Mus., Pretoria, South Africa. Subm. 1969 by E. van Rensburg, Nat. Cult. Hist. Mus., Pretoria. Comment: pretreated with acid only. Mummies with 
mummy portraits from Fayum historically dated to 2nd and 3rd centuries A.D. (Zaloscer, 1961).

Pta-227. Frauenchiemsee, Germany

$$
\begin{gathered}
1090 \pm \mathbf{5 0} \\
\text { A.D. 860 } \\
\delta C^{1 s}=-28.2 \%
\end{gathered}
$$

Outer tree rings of beam to left of entrance, $\mathrm{S}$ wall, of medieval building on Frauenchiemsee I. in Chiemsee $\left(47^{\circ} 52^{\prime} \mathrm{N}\right.$ Lat, $12^{\circ} 27^{\prime} \mathrm{W}$ Long), E of Rosenheim, Bavaria, Germany. Coll. and subm. 1970 by V. Milojčić, Inst. f. Ur- u. Frühgeschichte, Univ. Heidelberg, Germany. Comment: pretreated with acid and alkali. Dates construction of ground floor of portal, considered built either between A.D. 850 and A.D. 880 or in 11th century. Correction of result with $\mathrm{C}^{14}$ calibration curve (Suess, 1970) could make date $60 \mathrm{yr}$ later, still favoring earlier construction date.

\section{GEOPHYSICAL SAMPLES}

\section{Pretoria series, South Africa}

Atmospheric $\mathrm{CO}_{2}$ coll. at Nat. Physical Research Lab. $\left(25^{\circ} 43^{\prime} \mathrm{S}\right.$

\begin{tabular}{|c|c|c|c|c|c|}
\hline Sample no. & & Date & & $\delta \mathbf{C}^{13}(\% o)$ & $\Delta(\% o)^{*}$ \\
\hline Pta-117 & Oct. & 7 - Oct. & 10,1968 & -7.7 & $571 \pm 7$ \\
\hline Pta-121 & Nov. & 4 - Nov. & 18,1968 & -7.6 & $577 \pm 6$ \\
\hline Pta-122 & Dec. & 9 - Dec. & 23,1968 & $(-7.5)^{* *}$ & $561 \pm 7$ \\
\hline Pta-120 & Jan. & $20-$ Jan. & 28,1969 & -8.2 & $560 \pm 8$ \\
\hline Pta-123 & Feb. & 17 - Mar. & 4,1969 & -7.0 & $558 \pm 7$ \\
\hline Pta-119 & Mar. & 17 - Mar. & 24,1969 & -7.2 & $541 \pm 6$ \\
\hline Pta-131 & Apr. & $15-A p r$. & 24,1969 & -7.3 & $542 \pm 7$ \\
\hline Pta-130 & July & 15 - July & 28,1969 & $(-7.5) * *$ & $529 \pm 7$ \\
\hline Pta-124 & Sept. & 9 - Oct. & 13,1969 & -7.9 & $545 \pm 7$ \\
\hline Pta-118 & Oct. & 28 - Nov. & 23,1969 & -8.0 & $528 \pm 6$ \\
\hline Pta-142 & Jan. & 12 - Jan. & 26,1970 & -6.7 & $529 \pm 7$ \\
\hline Pta-166 & Feb. & $19-$ Feb. & 26,1970 & -7.6 & $541 \pm 7$ \\
\hline Pta-184 & Mar. & 9 - Mar. & 17,1970 & -7.9 & $558 \pm 7$ \\
\hline Pta-199 & Apr. & $13-$ Apr. & 20,1970 & -7.6 & $547 \pm 7$ \\
\hline Pta-220 & May & 12 - Мау & 17,1970 & -7.6 & $533 \pm 7$ \\
\hline Pta-266 & June & 6 - June & 22,1970 & -7.5 & $533 \pm 9$ \\
\hline Pta-264 & July & 14 - July & 20,1970 & -9.7 & $550 \pm 10$ \\
\hline Pta-294 & July & 28 - Aug. & 3,1970 & -8.6 & $517+9$ \\
\hline Pta-332 & Sept. & $21-$ Sept. & 28,1970 & -7.8 & $532 \pm 8$ \\
\hline
\end{tabular}
Lat, $28^{\circ} 21^{\prime}$ E Long), $9 \mathrm{~km}$ E of Pretoria, South Africa, by slowly pumping air through $1.5 \mathrm{~N} \mathrm{NaOH}$ solution.

${ }^{*} \mathrm{C}^{14}$ surplus, adjusted to $\delta \mathrm{C}^{13}=-25 \%$

** $\mathrm{C}^{13}$ value estimated

Comment: no significant rise caused by French nuclear weapon tests in 1968 and 1970 at about same Lat $\left(22^{\circ} \mathrm{S}\right)$ in Pacific Ocean. Development 
of relative $\mathrm{C}^{14}$ content in air at Pretoria since 1954 shown in Fig. 2, lower curve. Based on samples measured at Heidelberg, Germany, Groningen, Netherlands (R., 1970, v. 12, p. 468), and Pretoria, above. For period 1966 to 1968, samples from Bariloche, Argentina (R., 1969, v. 11, p. 385) are also included. For comparison, curve for central Europe based mainly on measurements at Heidelberg also given (Münnich and Vogel, 1963; Münnich and Roether, 1967, extended by courtesy K. O. Münnich, Heidelberg). Slight seasonal fluctuation and gradual decrease in S hemisphere since 1965 is apparent.

\section{Ocean Water series}

Surface ocean water samples coll. on voyages of MS RSA from Cape Town to Sanae, Antarctica, in Jan. 1969 and Jan. 1970 by officers of Dept.
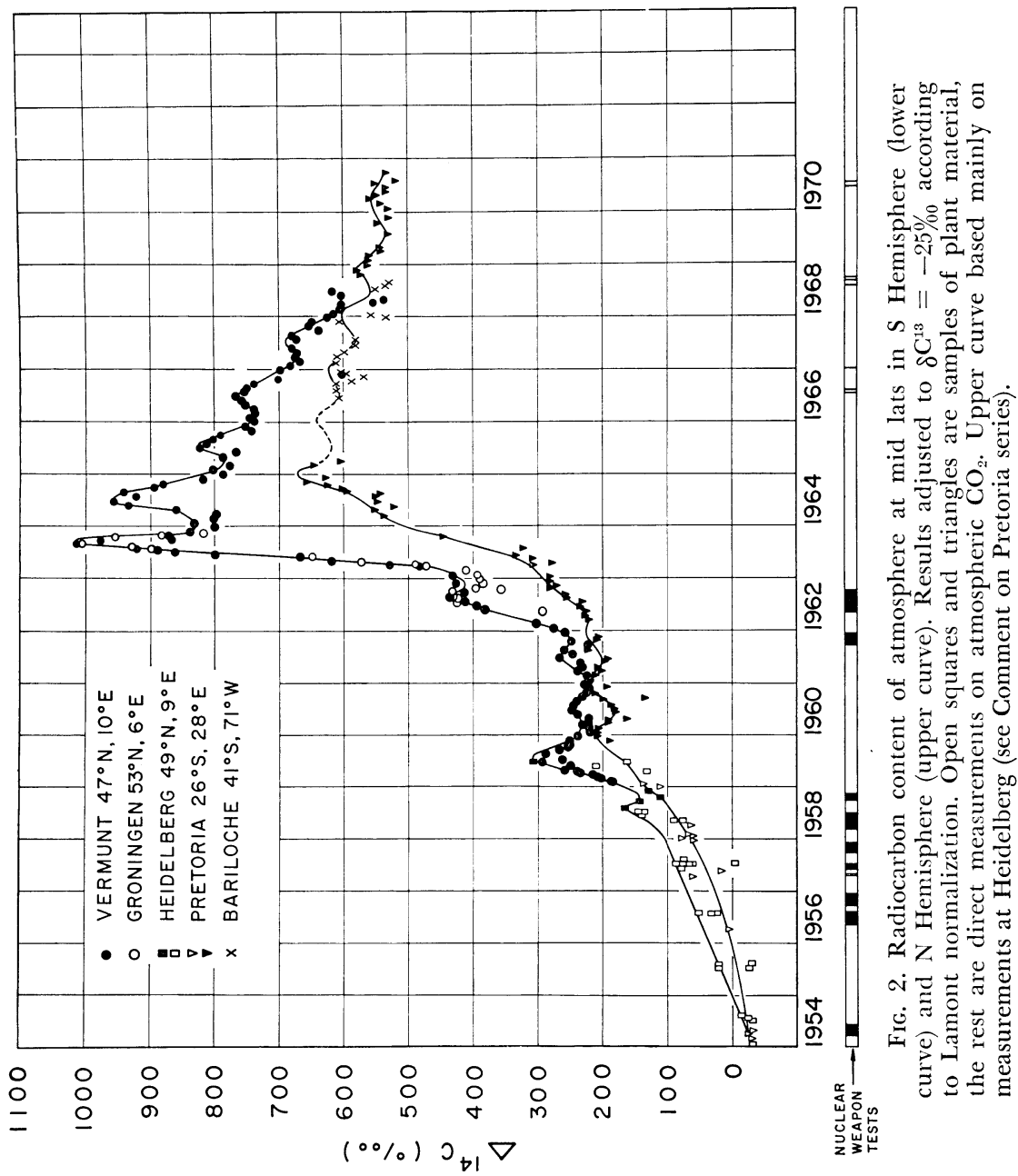
of Transport, Rep. of South Africa; and on voyage of MS Kaapland in Nov. 1969 and MS Stellenbosch in Jan./Feb. 1970 between Durban and Europe by J. C. Vogel, Sr. with generous help of Capts. Reiche and Rolff, officers, and crews. Inorganic carbon extracted by method described by Vogel (1967).

\begin{tabular}{clrlrr}
\hline & \multicolumn{1}{c}{ Lat, Long } & $\delta \mathrm{C}^{13}(\%)$ & \multicolumn{1}{c}{$\mathrm{C}^{14}(\%$} \\
modern $)$
\end{tabular}

Comment: for series coll. in 1967, see R., 1970, v. 12, p. 469. Unexpectedly low values between $50^{\circ} \mathrm{S}$ and $65^{\circ} \mathrm{S}$ indicate water not derived from Atlantic ocean deep water, but rather from Pacific-Antarctic basin. Low values in Atlantic ocean (Pta-160, Pta-155) due to upwelling near African coast. Otherwise low lats in S Atlantic uniform at $+12 \%$ and $\mathrm{N}$ Atlantic at ca. $+20 \%$, indicating a rise of $4 \%$ since mid 1967. As yet, no explanation for occasional higher values in S hemisphere (Pta-156).

\section{REFERENCES}

Dos Santos, Jr., J. R., and Ervedosa, C. M. N., 1970, A Estacao arqueologica de Benfica, Luanda-Angola: Estudos Biol. Fac. Ciências Univ. Luanda, Angola, v. 1, no. 1, p. $31-51$.

Dutton, T. P., 1970, Iron smelting furnace dated $630 \pm 40$ years A.D. in the Ndumu Game Reserve: Lammergeyer, no. 12, p. 37-40.

Humphreys, A. J. B. and Maggs, T. M. O'C., 1970, Further graves and cultural material from the banks of the Riet River: S. African Archeol. Bull., v. 25, p. 116-135.

Lowe, C. van Riet, 1931, Early graves in the Riet River valley: South African Jour. Sci., v. 27 , p. $430-434$

MacCalman, H. R., 1965, Carbon 14 dates from South West Africa: S. African Archaeol. Bull., v. 20, p. 215. 
Malan, B. D., 1952, The final phase of the Middle Stone age in South Africa: PanAfrican Cong. on Prehistory Proc., Nairobi, 1947, Oxford, p. 188-194.

Mason, J. R., 1969, The Oppermansdrif dam archaeological project-Vaal basin: South African Archaeol. Bull., v. 24, p. 182-192.

Münnich, K. O. and Roether, W., 1967, Transfer of bomb ${ }^{14} \mathrm{C}$ and $\mathrm{T}$ from the atmosphere to the ocean, in: Radioactive dating and methods of low level counting: I.A.E.A., Vienna, p. 93-104.

Münnich, K. O. and Vogel, J. C., 1959, C14-Altersbestimmung von Süsswasser-Kalkablagerungen: Naturwissenschaften, v. 46, p. 168-169.

1963, Investigation of meridional transport in the troposphere by means of carbon-14 measurements, in: Radioactive dating: I.A.E.A., Vienna, p. 189-197.

Rudner, J., 1957, The Brandberg and its archaeological remains: South West African Sci. Soc. Jour., v. 12, p. 7-44.

Singer, R. and Wymer, J., 1969, Radiocarbon date for two painted stones from a coastal cave in South Africa: Nature, v. 224, p. 508-510.

Stuiver, Minze, 1969, Yale natural radiocarbon measurements IX: Radiocarbon, v. 11, p. $545-658$.

Suess, H., 1970, Bristlecone pine calibration of the Radiocarbon time scale 5200 B.c. to the present, in: Olsson, I. U. (ed.), Radiocarbon variations and absolute chronology, 12th Nobel Symposium Proc., Stockholm, Alonquist, p. 303-311.

Vogel, J. C., 1967, Investigation of groundwater flow with Radiocarbon, in: Isotopes in hydrology, I.A.E.A., Vienna, p. 355-369.

1970, Groningen radiocarbon dates IX: Radiocarbon, v. 12, p. 444-471.

Vogel, J. C. and Waterbolk, H. T., 1963, Groningen radiocarbon dates IV: Radiocarbon, v. 5, p. 163-202

1967, Groningen radiocarbon dates VII: Radiocarbon, v. 9, p. 107-155.

Zaloscer, Hilde, 1961, Porträts aus dem Wüstensand: Wien-München, Verlag A. Schroll. 